\title{
PERILAKU LENTUR BALOK BETON BERTULANG HIGH VOLUME FLY ASH SELF COMPACTING CONCRETE (HVFA-SCC) USIA 90 HARI.
}

\author{
Reyhan Prastha Wijaya'), Agus Setiya Budi'), Stefanus Adi Kristiawan ${ }^{3)}$ \\ 1) Mahasiswa Fakultas Teknik, Prodi Teknik Sipil, Universitas Sebelas Maret \\ 2) Pengajar Fakultas Teknik, Prodi Teknik Sipil, Universitas Sebelas Maret \\ 3) Pengajar Fakultas Teknik, Prodi Teknik Sipil, Universitas Sebelas Maret \\ Jl. Ir. Sutami 36A, Kentingan Surakarta 57126; Telp. (0271) 634524, Fax 662118 Email : reypras8@gmail.com
}

\begin{abstract}
Abstrack
Fly ash is a coal combustion waste that has a chemical content of silica and alumina reaches $80 \%$. The compound reacts with $\mathrm{Ca}(\mathrm{OH})_{2}$ of the cement hydration process and forms $\mathrm{C}_{3} \mathrm{~S}_{2} \mathrm{H}_{3}$ or tubermorite which can increase the strength of the concrete. The use of fly ash in large quantities of $50 \%$ cement substitution and superplastictizer addition can produce ductile concrete structure and can be self compacting or called High Volume Fly Ash - Self Compacting Concrete (HVFA-SCC). In the application can also be used for the manufacture of reinforce concrete beam. This study examined bending beam behavior with the addition of $50 \%$ flay ash in reinforced concrete beams and compared with normal concrete beam bending. The method used is an experiment where 3 beams of reinforced concrete HVFA-SCC and 3 reinforced concrete normal beams with $2000 \mathrm{~mm}, 150 \mathrm{~mm}$ wide, and $300 \mathrm{~mm}$ height. The samples were uniform based on the quality of $40 \mathrm{MPa}$. HVFA-SCC fresh concrete test was performed with 3 methods: flow table test, L-box test, and V-funnel test. While on the normal concrete slump testing. While for beam testing use a frame loading tool that will be loaded with 2 pieces of loading point on 1/3 span looking for strong bending of the beam. From the results of the research it is found that in reinforced concrete beams HVFA-SCC has a larger deflection than normal reinforced concrete beams but normal reinforced concrete beams can receive larger loads than HVFA-SCC reinforced concrete blocks.
\end{abstract}

Keyword : fly ash, bvfa-scc, storng bending

\begin{abstract}
Abstrak
Fly ash merupakan limbah pembakaran batu bara yang memiliki kandungan kimia berupa silika dan alumina mencapai $80 \%$. Senyawa tersebut bereaksi dengan $\mathrm{Ca}(\mathrm{OH})_{2}$ hasil proses hidrasi semen dan membentuk $\mathrm{C}_{3} \mathrm{~S}_{2} \mathrm{H}_{3}$ atau tubermorite yang dapat menambah kekuatan beton. Penggunaan fly ash dalam jumlah besar yaitu 50\% subtitusi semen dan penambahan superplastictizer mampu menghasilkan struktur beton yang daktail dan dapan mengalir sendiri atau disebut High Volume Fly Ash - Self Compacting Concrete (HVFA-SCC). Pada pengaplikasiannya dapat digunakan juga untuk pembuatan balok beton bertulan. Penelitian ini mengkaji perilaku lentur balok dengan penambahan $50 \%$ flay ash pada balok beton bertulang dan dibandingkan dengan lentur balok beton normal. Metode yang digunakan adalah eksperimen dimana digunakan 3 balok beton bertulang HVFA-SCC dan 3 balok beton bertulang normal dengan dimensi panjan $2000 \mathrm{~mm}$, lebar $150 \mathrm{~mm}$, dan tinggi $300 \mathrm{~mm}$. Sampel tersebut diseragamkan berdasarkan mutu yaitu $40 \mathrm{MPa}$. Pengujian beton segar HVFA-SCC dilakukan dengan 3 metode yaitu : flow table test, L-box test, dan $V$-funnel test. Sedangkan pada beton normal dilakukan pengujian slump. Pengujian balok menggunakan alat loading frame yang akan dibebani dengan 2 buah titik pembebanan pada $1 / 3$ untuk mencari kuat lentur balok tersebut. Dari hasil penelitian didapatkan bahwa pada balok beton bertulang HVFASCC memiliki lendutan yang lebih besar dari pada balok beton bertulang normal akan tetapi balok beton bertulang normal dapat menerima beban yang lebih besar dari pada balok beton bertulang HVFA-SCC.
\end{abstract}

Kata kunci : fly ash, hvfa-scc, kuat lentur

\section{PENDAHULUAN}

Tingkat pertumbuhan penduduk yang semakin meningkat menyebabkan kebutuhan tempat tinggal ikut meningkat. Seiring berkembangnya era maka banyak cara yang dapat dilakukan oleh pemerintah diantaranya membuat rumah susun, apartemen dan bangunan tinggi lainnya. Pada pembangunan infrastruktur ini beton masih menjadi pilihan utama sebagai komponen penyusun bangunan tersebut. Hal ini dikarenakan beton memiliki kelebihan yaitu kekuatannya yang sangat baik, harganya relatif murah, bahan baku yang mudah untuk didapatkan, serta tahan terhadap api dan lain-lain.

Dalam proses pembuatannya, campuran beton terdiri dari pasir, kerikil, semen dan air. Penggunaan semen dalam pembuatan beton normal merupakan salah satu hal pemicu terjadinya Global Warming. Pembuatan atau produksi semen menciptakan emisi gas $\mathrm{CO}_{2}$ yang cukup segnifikan, pada tahun 2007 industri produksi semen menyumbang 4,5\% emisi gas $\mathrm{CO}_{2}$ yang memicu terjadinya Global Warming. Dapat dihitung untuk setiap 1 kilogram semen yang dihasilkan dari industri produksi semen, memancarkan emisi gas $\mathrm{CO}_{2}$ sebanyak 1 kilogram (M. Arezoumandi, C.A. Ortega, and J.S. Volz, 2014). 
Fy ash merupakan hasil sisa pembakaran batu bara yang dapat digunakan untuk mensubstitusi semen karena memiliki sifat pozzolan. Penggunaan fly ash dengan kadar lebih dari 50\% serta penambahan superplastictizer mampu menghasilkan struktur beton yang daktail dan dapat mengalir sendiri. Dalam pengaplikasiannya dapat dilakukan dengan pembuatan balok beton bertulang High Volume Fy Ash - Self Compacting Concrete (HVFA-SCC).

Beton memiliki ciri khas kuat tekan yang sangat baik sedangkan untuk kuat tarik sendiri bisa dibilang kurang baik. Untuk mengatasi hal ini maka dalam pembuatan balok beton sering diberikan tulangan yang berfungsi untuk meningkatkan kuat lentur pada beton tersebut. Dengan penambahan I dapat meningkatkan kerjasama kekuatan antara tulangan dan juga HVFA-SCC. Penelitian ini akan dikaji perilaku lentur balok beton High Volume Fly Ash Self Compacting Concrete (HVFA-SCC) dengan kadar fly ash 50\% dari berat semen dan kemudian akan dibandingkan dengan balok beton normal. Balok beton HVFA-SCC akan diuji pada umur 90 hari dan balok normal akan diuji pada umur 28 hari.

\section{LANDASAN TEORI}

\section{Pengertian Self Compacting Concrete (SCC)}

Menurut (Slamet Widodo, 2004), Self-compacting Concrete (SCC) dapat didefinisikan sebagai suatu jenis beton yang dapat dituang, mengalir dan menjadi padat dengan memanfaatkan berat sendiri, tanpa memerlukan proses pemadatan dengan getaran atau metode lainnya, selain itu beton segar jenis self-compacting concrete bersifat kohesif dan dapat dikerjakan tanpa terjadi segregasi atau bleeding.

Menurut Okamura H. (1995) kriteria bahan campuran pada beton SCC adalah sebagai berikut:

1. SCC memerlukan agregat halus yang lebih banyak dibandingkan dengan beton konvensional.

2. Ukuran agregat kasar biasanya antara $12 \mathrm{~mm}$ sampai $20 \mathrm{~mm}$.

3. Semen dan fly ash diberikan sesuai perbandingan binder.

4. Untuk mendapatkan workabilitas yang tinggi dan homogenitas beton diperlukan viscocrete admixtures.

Perbedaan utama self compacting concrete (SCC) dibandingkan dengan beton konvensional terletak pada komposisi campuran beton, yaitu penggunaan porsi bahan pengisi sekitar $40 \%$ dari volume total campuran. Bahan pengisi ini adalah pasir butiran halus dengan ukuran maksimum kurang dari $0,125 \mathrm{~mm}$. Porsi besar bahan ini menyebabkan campuran beton cenderung seperti pasta (Okamura dan Ouchi, 2003).

Menurut EFNARC Specification and Guidelines for Self - Compacting Concrete (2002), metode test yang digunakan untuk membuat beton SCC adalalah :

1. Slump Flow Test

2. L-Shape Box

3. $V$-funnel

4. J-Ring Flow Table

\section{Pengertian High Volume Fly Ash (HVFA)}

Beton dengan penggunaan fly ash dalam prosentase tinggi disebut high volume fly ash concrete (HVFAC) adalah beton dimana setidaknya minimal 50\% pengunaan jumlah semen sebagai bahan pengikat digantikan fly ash baik berupa kelas F fly ash maupun kelas C fly ash. Menurut ASTM C-618, penggunaan fly ash untuk tipe F dibatasi pada nilai 15\% - 20\%, sedangkan untuk tipe C dibatasi pada nilai 25\% - 35\% dari total berat binder (Mochamad Solikin, 2012).

Menurut (Yash Shrivastavab dan Ketan Bajaj, 2012) Penelitian pada bigh volume fly ash concrete telah menunjukkan bahwa high volume fly ash concrete lebih tahan retak daripada beton konvensional, penurunan panas hidrasi high volume fly ash concrete pada usia dini mengurangi potensi susut termal dan retak. Hal ini disebabkan dari hasil penurunan pencampuran air dibandingkan semen $(w / \mathrm{cm})$ rasio, dan juga penurunan total volume pasta semen yang diperlukan dalam high volume fly ash concrete. Salah satu indikator dari durabilitas high volume fly ash concrete baik adalah bahwa nilai permeabilitas semakin mengecil dibandingakan beton konvensional, dikarenakan dengan semakin banyak air yang dapat menembus beton, beton lebih rentan terhadap kerusakan pembekuan atau pencairan.

\section{Kuat Lentur}


Pengujian lentur pada beton dilakukan dengan cara uji kuat lentur beton normal dengan dua titik pembebanan, mengacu pada SNI 4431:2011. Pengujian ini dilakukan dengan benda uji berupa balok uji, yakni balok beton berpenampang bujur sangkar dengan panjang total balok empat kali lebar penampangnya (SNI 03-4154-1996:1).

Balok uji dibuat dengan mengacu pada SNI 2493 : 2011 tentang tata cara pembuatan dan perawatan benda uji beton di laboratorium, yakni dengan bentuk benda uji Prismatik berupa balok sebagai uji lentur (SNI 2493 2011:6).

Pengujian dilakukan secara masinal dimana benda uji yang diletakkan pada dua tumpuan, dibebani secara terpusat pada bagian tengah dari panjang benda uji, kecepatan pembebanan harus dilakukan secara kontinu tanpa menimbulkan efek kejut. Metode pengujian ini dapat dilihat pada gambar sebagai berikut:

Keterangan gambar :

$$
\begin{array}{ll}
\text { A - A } & \text { sumbu memanjang } \\
\text { B } & \text { titik - titik perletakan } \\
\text { C } & \text { titik - titik pembebanan }
\end{array}
$$

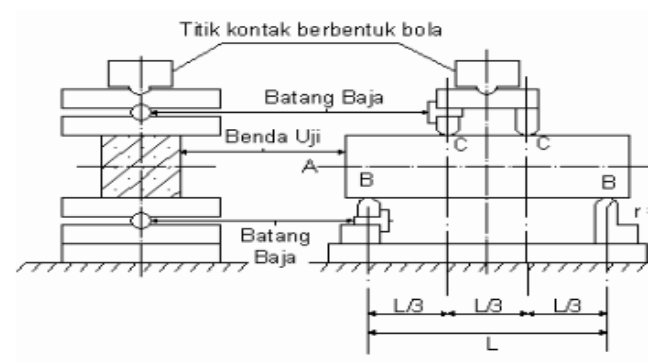

Gambar 1. Perletakan dan Pembebanan
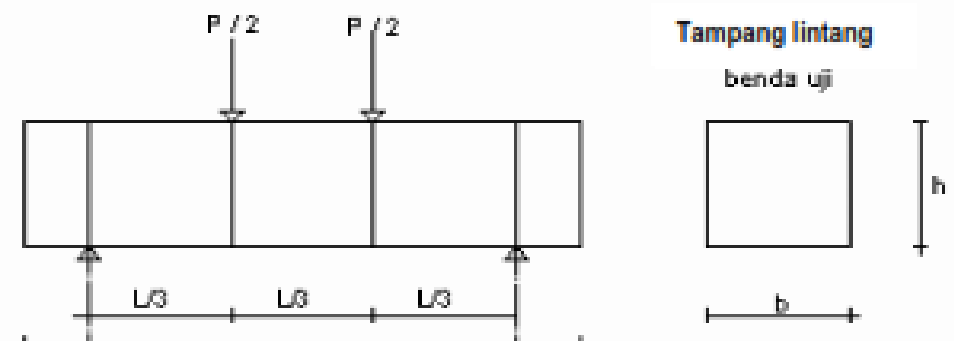

Keterangan gambar: $\quad \mathrm{L}=$ jarak antara dua garis perletakan

$\mathrm{b}=$ dalah lebar tampak lintang benda uji

$\mathrm{h}=$ tinggi tampak lintang benda uji

$\mathrm{P}=$ beban tertinggi yang ditunjukkan mesin uji

Gambar 2. Garis - Garis Perletakan dan Pembebanan

\section{METODE PENELITIAN}

Metode penelitian dalam penelitian ini adalah eksperimental yang dilakukan di Laboratorium Bahan dan Laboratorium Struktur Teknik Sipil Fakultas Teknik Universitas Sebelas Maret. Benda uji yang digunakan dalam penelitian ini berbentuk balok dengan dimensi panjang $2000 \mathrm{~mm}$, lebar $150 \mathrm{~mm}$, dan $300 \mathrm{~mm}$ dengan kadar fly ash 50\% dan $0 \%$ (normal). Tiap variasi terdiri dari 3 buah balok yang akan diuji pada umur 90 hari untuk balok HVFA-SCC dan 28 hari untuk beton normal. Pengujian yang dilakukan adalah pengujian kuat lentur dengan menggunakan alat loading frame dan lentur balok dibaca menggunakan dial gange. Selanjutnya data hasil pengujian akan diolah menggunakan Microsoft Excel. Model benda uji dapat dilihat pada Gambar 3.

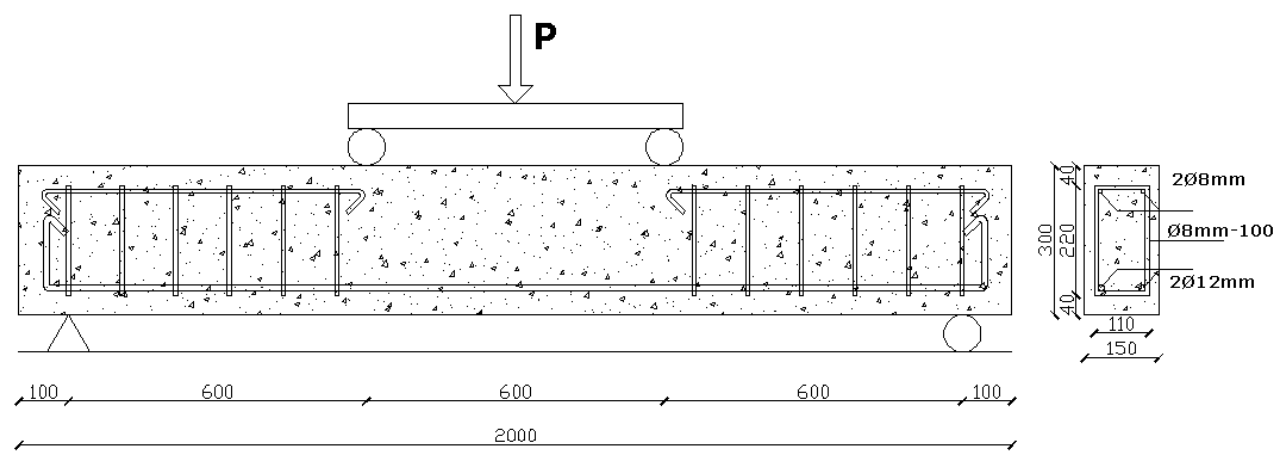


HASIL DAN PEMBAHASAN

Hasil Pengujian Material

Pengujian terhadap agregat kasar meliputi pengujian berat jenis (specific gravity), keausan (abrasi) dan gradasi agregat kasar. Hasil pengujian agregat kasar disajikan dalam Tabel 1.

Tabel 1. Hasil Pengujian Agregat Kasar

\begin{tabular}{ccccc}
\hline No & Jenis Pengujian & Hasil Pengujian & Standar & Kesimpulan \\
\hline 1 & Absorbtion & $0,83 \%$ & - & - \\
\hline 2 & Apparent Specific Gravity & $2,6690 \mathrm{gr} / \mathrm{cm}^{3}$ & - & - \\
\hline 3 & Bulk Specific Gravity & $2,6109 \mathrm{gr} / \mathrm{cm}^{3}$ & - & - \\
\hline 4 & Bulk Specific SSD & $2,6327 \mathrm{gr} / \mathrm{cm}^{3}$ & $2,5-2,7 \mathrm{gr} / \mathrm{cm}^{3}$ & Memenuhi syarat \\
\hline 5 & Modulus Halus Butir & 8,3640 & $5-8$ & Memenuhi syarat \\
\hline
\end{tabular}

Pengujian agregat halus meliputi pengujian kadar lumpur, kandungan zat organik, specific gravity, gradasi agregat dan berat jenis. Hasil-hasil pengujian tersebut disajikan dalam Tabel 2.

Tabel 2. Hasil Pengujian Agregat Halus

\begin{tabular}{ccccc}
\hline No & Jenis Pengujian & Hasil Pengujian & Standar & Kesimpulan \\
\hline 1 & Absorbtion & $0.83 \%$ & - & - \\
\hline 2 & Apparent Specific Gravity & $2,6690 \mathrm{gr} / \mathrm{cm}^{3}$ & - & - \\
\hline 3 & Bulk Specific Gravity & $2,6109 \mathrm{gr} / \mathrm{cm}^{3}$ & - & - \\
\hline 4 & Bulk Specific SSD & $2,6327 \mathrm{gr} / \mathrm{cm}^{3}$ & $2,5-2,7 \mathrm{gr} / \mathrm{cm}^{3}$ & Memenuhi syarat \\
\hline 5 & Modulus Halus Butir & 8,3640 & $5-8$ & Memenuhi syarat \\
\hline
\end{tabular}

Fly ash yang digunakan dalam penelitian ini berasal dari PLTU Paiton. Pengujian fly ash sendiri dilakukan di dua tempat yaitu di Laboratorium Tanah Universitas Sebelas Maret untuk mengetahui berat jenis dan di Laboratorium MIPA Terpadu Universitas Sebelas Maret untuk mengetahui kandungan kimia. Setelah dilakukan pengujian didapatkan bahwa berat jenis fly ash sebesar $2,8 \mathrm{gr} / \mathrm{cm}^{3}$ dan dari hasil uji kandungan kimia, fly ash dari PLTU Paiton tergolong dalam tipe F. Hasil pengujian fly ash berdasarkan parameter yang diteliti dapat dilihat pada Tabel 3.

Tabel 3. Komposisi Kimia Fly Ash

\begin{tabular}{cccccccccc}
\hline $\mathbf{S i O}_{2}$ & $\mathbf{A l}_{\mathbf{2}} \mathbf{O}_{3}$ & $\mathbf{F e}_{2} \mathbf{O}_{3}$ & $\mathbf{T i O}_{2}$ & $\mathbf{C a O}$ & $\mathbf{M g O}$ & $\mathbf{K}_{\mathbf{2}} \mathbf{O}$ & $\mathbf{P}_{2} \mathbf{O}_{\mathbf{5}}$ & $\mathbf{S O}_{3}$ & $\mathbf{M n O}$ \\
\hline 39.69 & 13.23 & 23.43 & 1.60 & 10.91 & 3.93 & 2.72 & 1.13 & 1.81 & 0.28 \\
\hline
\end{tabular}

Pengujian kuat tarik baja pada penelitian ini dilakukan di Laboratrium Program Studi Teknik Mesin, Fakultas Teknik Universitas Sebelas Maret dengan menggunakan mesin UTM (Universal Testing Macbine). Benda uji yang digunakan merupakan potongan tulangan baja yang digunakan pada pembuatan benda uji balok beton bertuang dengan dimensi tulangan $\varnothing 12 \mathrm{~mm}$ untuk tulangan lentur dan $\varnothing 8 \mathrm{~mm}$ untuk sengkang. Hasil pengujian dapat dilihat pada Tabel 4 dan Tabel 5

Tabel 4. Hasil Pengujian Kuat Tarik Baja Ø $12 \mathrm{~mm}$

\begin{tabular}{|c|c|c|c|c|c|c|c|}
\hline $\begin{array}{l}\text { Kode } \\
\text { Benda } \\
\text { Uji }\end{array}$ & $\begin{array}{l}\text { Diameter } \\
\text { Baja }(\mathrm{mm})\end{array}$ & $\begin{array}{l}\text { Rerata } \\
(\mathrm{mm})\end{array}$ & $\begin{array}{l}\text { Luas penampang } \\
\left(\mathrm{mm}^{2}\right)\end{array}$ & $\begin{array}{l}\mathbf{P}_{\text {leleh }} \\
(\mathbf{N})\end{array}$ & $\begin{array}{l}P_{\text {maks }} \\
(\mathbf{N})\end{array}$ & $\begin{array}{l}\text { Kuat Tarik } \\
\text { Leleh } \\
\text { (MPa) }\end{array}$ & $\begin{array}{c}\text { Kuat Tarik } \\
\text { Maksimum } \\
\text { (MPa) }\end{array}$ \\
\hline A & 12 & \multirow{3}{*}{12} & \multirow{3}{*}{113.1429} & 44500 & 64160 & 393.31 & 567.07 \\
\hline B & 12 & & & 45000 & 64850 & 397.73 & 573.17 \\
\hline $\mathrm{C}$ & 12 & & & 44000 & 63910 & 388.89 & 564.86 \\
\hline \multicolumn{6}{|c|}{ Rerata } & 393.31 & 568.367 \\
\hline
\end{tabular}

Tabel 5. Hasil Pengujian Kuat Tarik Baja Ø 8 mm 


\begin{tabular}{|c|c|c|c|c|c|c|c|}
\hline $\begin{array}{c}\text { Kode } \\
\text { Benda Uji }\end{array}$ & $\begin{array}{l}\text { Diameter } \\
\text { Baja } \\
(\mathrm{mm})\end{array}$ & $\begin{array}{l}\text { Rerata } \\
(\mathrm{mm})\end{array}$ & $\begin{array}{l}\text { Luas penampang } \\
\left(\mathrm{mm}^{2}\right)\end{array}$ & $\begin{array}{l}\mathbf{P}_{\text {leleh }} \\
(\mathbf{N})\end{array}$ & $\begin{array}{l}\mathbf{P}_{\text {maks }} \\
(\mathbf{N})\end{array}$ & $\begin{array}{c}\text { Kuat Tarik } \\
\text { Leleh (MPa) }\end{array}$ & $\begin{array}{l}\text { Kuat Tarik } \\
\text { Maksimum } \\
\text { (MPa) }\end{array}$ \\
\hline 1 & 8 & \multirow{3}{*}{8} & \multirow{3}{*}{50,2857} & 19300 & 24600 & 383.81 & 489.21 \\
\hline 2 & 8 & & & 16800 & 21800 & 334.09 & 433.52 \\
\hline 3 & 8 & & & 18500 & 24110 & 367.9 & 479.46 \\
\hline \multicolumn{4}{|c|}{ Rerata } & & & 326,93 & 467.4 \\
\hline
\end{tabular}

\section{Rancang Campur (Mix Design)}

Rancang campur (mix design) pada penelitian HVFA-SCC dan beton normal dibuat untuk volume sebesar $1 \mathrm{~m}^{3}$. Rancang campur (mix design) dapat dilihat pada Tabel 6 sebagai berikut :

Tabel 6. Rancang Campur Beton High Volume Fly Ash - Self Compacting Concrete dan Beton Normal

$$
\begin{array}{cccccccc}
\text { Kode } & \begin{array}{c}
\text { Persentase } \\
\text { Fly Ash }
\end{array} & \begin{array}{c}
\text { Semen } \\
\left(\mathrm{kg} / \mathrm{m}^{3}\right)
\end{array} & \begin{array}{c}
\text { Fly Ash } \\
\left(\mathrm{kg} / \mathrm{m}^{3}\right)
\end{array} & \begin{array}{c}
\text { Kerikil } \\
\left(\mathrm{kg} / \mathrm{m}^{3}\right)
\end{array} & \begin{array}{c}
\text { Pasir } \\
\left(\mathrm{kg} / \mathrm{m}^{3}\right)
\end{array} & \begin{array}{c}
\text { Air } \\
\left(\mathrm{lt} / \mathrm{m}^{3}\right)
\end{array} & \begin{array}{c}
\text { Sp } \\
\left(\mathrm{lt} / \mathrm{m}^{3}\right)
\end{array}
\end{array}
$$

\begin{tabular}{cccccccc}
\hline HVFA28.50 & $50 \%$ & 250 & 250 & 889,33 & 886,79 & 135 & 10 \\
\hline NC28 & - & 450 & 0 & 970,99 & 773,30 & 150 & 5,2 \\
\hline
\end{tabular}

\section{Hasil Pengujian Beton Segar}

Pengujian HVFA-SCC terdiri dari Flow Table Test, L-Box Test, dan V-funnel Test, sedangkan beton normal dilakukan pengujian slump. Hasil pengujian tersebut disajikan dalam Tabel 7 sebagai berikut :

Tabel 7. Hasil Pengujian Beton Segar HVFA-SCC

\begin{tabular}{cccc}
\hline $\begin{array}{c}\text { Jenis } \\
\text { Pengujian }\end{array}$ & Parameter & $\begin{array}{c}\text { Hasil Pengujian Beton } \\
\text { Segar Kadar Fly } \text { Ash } \mathbf{5 0 \%}\end{array}$ & $\begin{array}{c}\text { Persyaratan Beton SCC } \\
\text { (EFNARC 2002) }\end{array}$ \\
\hline \multirow{2}{*}{ Flow Table } & Diameter $(\mathrm{mm})$ & $\mathbf{6 5 8 , 5}$ & $600-700 \mathrm{~mm}$ \\
\cline { 2 - 4 } & $\mathrm{t}_{50}(\mathrm{detik})$ & 4,6 & $2-5$ detik \\
\hline L-Box & $\mathrm{h} 2 / \mathrm{h} 1$ & 0,83 & $0,8-1,0$ \\
\hline \multirow{3}{*}{ V-funnel } & $\mathrm{t}($ detik) & 10,3 & $6-12$ detik \\
\cline { 2 - 4 } & $\mathrm{T}_{5 \text { menit }}(\mathrm{detik})$ & 11,7 & $0-3$ detik \\
\cline { 2 - 4 } & $\Delta \mathrm{t}(\mathrm{detik})$ & 1,4 & \\
\hline
\end{tabular}

Pada beton normal dilakukan pengujian slump dan didapat hasil adalah $11 \mathrm{~cm}$.

Hasil Pengujian Lentur Balok

Data beban dan lendutan hasil pengujian kapasitas lentur balok beton bertulang normal dan balok beton bertulang HVFA-SCC 50\% dapat dilihat pada Tabel 8 sebagai berikut :

Tabel 8. Hasil Pembacaan Dial Load Beton Normal

\begin{tabular}{ccccccc}
\hline \multirow{2}{*}{ Beban $(\mathbf{k N})$} & \multicolumn{7}{c}{ Lendutan $(\mathbf{m m})$} \\
\cline { 2 - 7 } & $\mathbf{N C 1}$ & $\mathbf{N C 2}$ & $\mathbf{N C 3}$ & HVFA 1 & HVFA 2 & HVFA 3 \\
\hline 0 & 0 & 0 & 0 & 0 & 0 & 0 \\
\hline 5 & 0.13 & 0.22 & 0.04 & 0.13 & 0.08 & 0.08 \\
\hline 10 & 0.19 & 0.31 & 0.11 & 0.22 & 0.16 & 0.19 \\
\hline 15 & 0.3 & 0.42 & 0.21 & 0.35 & 0.26 & 0.27 \\
\hline 20 & 0.42 & 0.54 & 0.3 & 0.47 & 0.37 & 0.39 \\
\hline 25 & 0.58 & 0.64 & 0.41 & 0.54 & 0.46 & 0.49 \\
\hline 30 & 0.8 & 0.75 & 0.51 & 0.63 & 0.6 & 0.61 \\
\hline 35 & 0.92 & 0.81 & 0.6 & 0.71 & 0.71 & 0.72 \\
\hline 40 & 1.04 & 0.93 & 0.73 & 0.84 & 0.86 & 0.85 \\
\hline 45 & 1.27 & 1.32 & 0.84 & 0.92 & 1.09 & 1 \\
\hline 50 & 1.67 & 1.75 & 1.42 & 1.03 & 1.3 & 1.28 \\
\hline
\end{tabular}




\begin{tabular}{|c|c|c|c|c|c|c|}
\hline 55 & 1.96 & 1.95 & 1.93 & 1.24 & 1.7 & 1.68 \\
\hline 60 & 2.41 & 2.24 & 2.28 & 1.55 & 1.99 & 2.19 \\
\hline 65 & 2.68 & 2.5 & 2.58 & 1.82 & 2.38 & 2.57 \\
\hline 70 & 2.9 & 3.1 & 3.4 & 2.73 & 2.66 & 2.97 \\
\hline 73 & 3.22 & 3.25 & 3.6 & 3.15 & 2.85 & 3.17 \\
\hline 76 & 3.98 & 5.7 & 5.16 & 4.23 & 3.19 & 3.52 \\
\hline 79 & 6.16 & 10.6 & 6.6 & 9.93 & 3.74 & 6.49 \\
\hline 81 & - & - & - & - & 5.1 & - \\
\hline \multirow{2}{*}{ Beban (kN) } & \multicolumn{6}{|c|}{ Lendutan $(\mathrm{mm})$} \\
\hline & NC1 & NC2 & NC3 & HVFA 1 & HVFA 2 & HVFA 3 \\
\hline 82 & 7.2 & 12.95 & 7.58 & 14.34 & - & 7.64 \\
\hline 83 & - & - & - & - & - & 10.16 \\
\hline 84 & - & - & - & - & - & 16.49 \\
\hline 85 & 8.38 & 18.75 & 8.9 & 21.65 & 6.53 & 24.7 \\
\hline 85 & - & - & - & - & - & 27.08 \\
\hline 86 & - & - & - & - & - & 30.19 \\
\hline 87 & 11.83 & 21.75 & - & - & - & 32.39 \\
\hline 88 & 17.38 & 27.28 & 13.65 & 32.6 & 8.32 & 38.08 \\
\hline 89 & 23.55 & - & - & - & - & - \\
\hline 90 & 26.78 & 32.9 & 20.1 & 43.88 & - & 42.79 \\
\hline 91 & 28.7 & - & - & - & 10.1 & 43.37 \\
\hline 92 & 31.79 & 38.76 & 21.2 & - & - & - \\
\hline 93 & 34.54 & - & - & - & 15.5 & 49.24 \\
\hline 94 & - & - & 23.94 & - & 17.64 & - \\
\hline 95 & 41.79 & - & - & - & 21.8 & - \\
\hline 96 & - & - & 27.19 & - & - & - \\
\hline 97 & - & - & - & - & 29.85 & - \\
\hline 98 & - & - & 30.1 & - & 30.85 & - \\
\hline 99 & - & - & - & - & 31.69 & - \\
\hline 100 & - & - & 34.82 & - & - & - \\
\hline
\end{tabular}

Dari tabel dapat dilihat bahwa balok beton bertulang HVFA-SCC memiliki lendutan yang lebih besar dari pada balok beton bertulang normal, akan tetapi balok beton bertulang normal dapat menerima beban lebih dari balok beton bertulang HVFA-SCC. Data pembacaan dial load dapat diolah menjadi grafik yang menggambarkan hubungan beban terhadap lendutan dari pengujian lentur balok beton bertulang yang dapat dilihat pada Gambar 4 sampai Gambar 9 sebagai berikut :

Hubungan Beban dan Lendutan NC 1

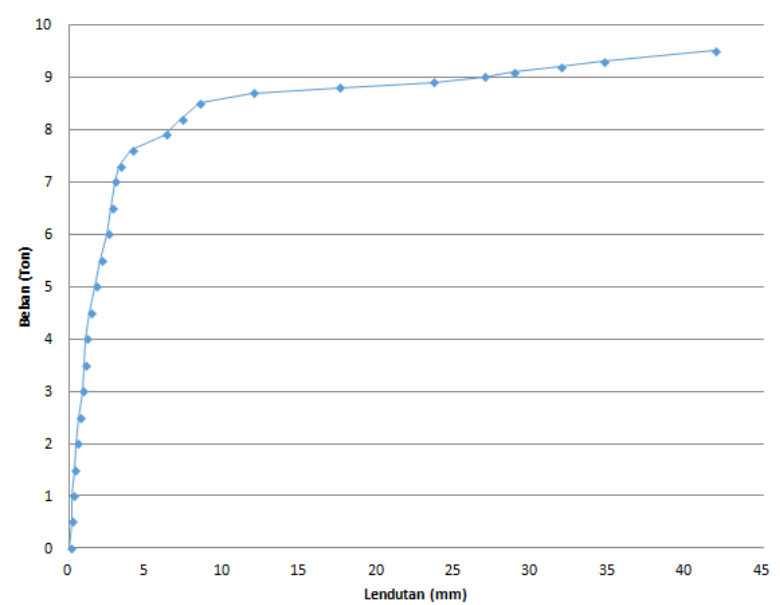

Hubungan Beban dan Lendutan NC 2

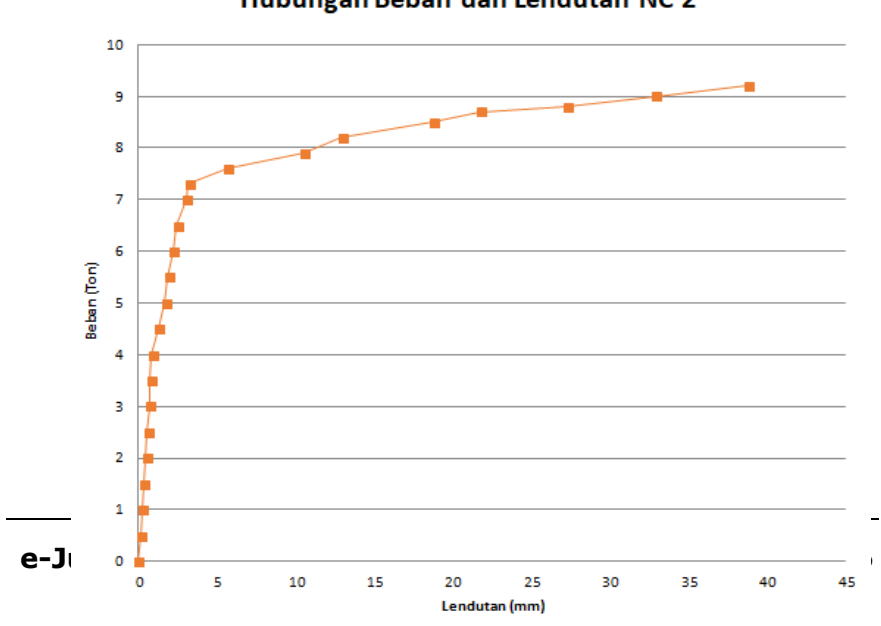


Gambar 4. Hubungan Beban dan Lendutan Balok Normal 1

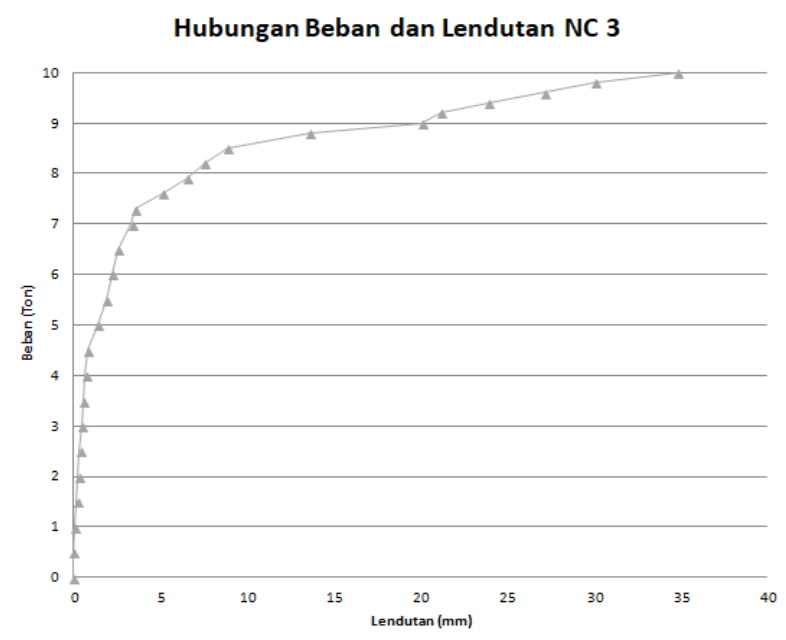

Gambar 6. Hubungan Beban dan Lendutan Balok Normal 3

Hubungan Beban dan Lendutan HVFA 2

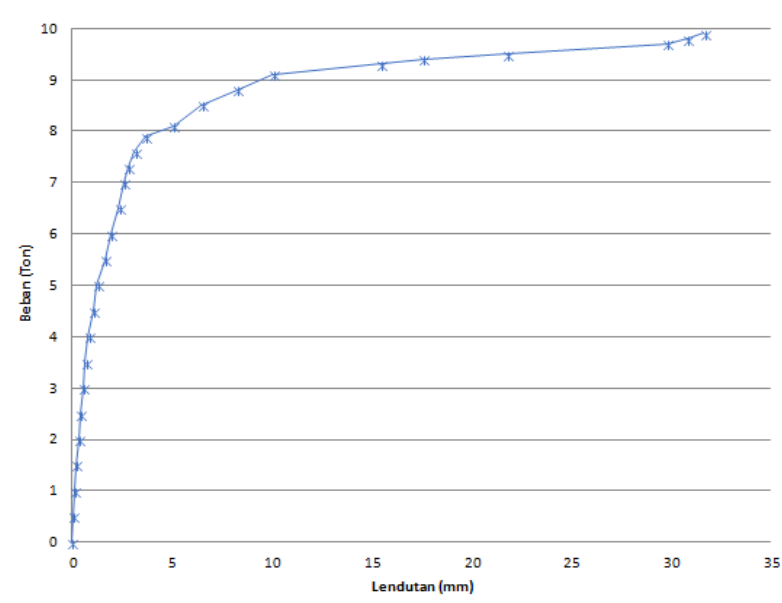

Gambar 8. Hubungan Beban dan Lendutan Balok HVFA 2
Gambar 5. Hubungan Beban dan

Lendutan Balok Normal 2

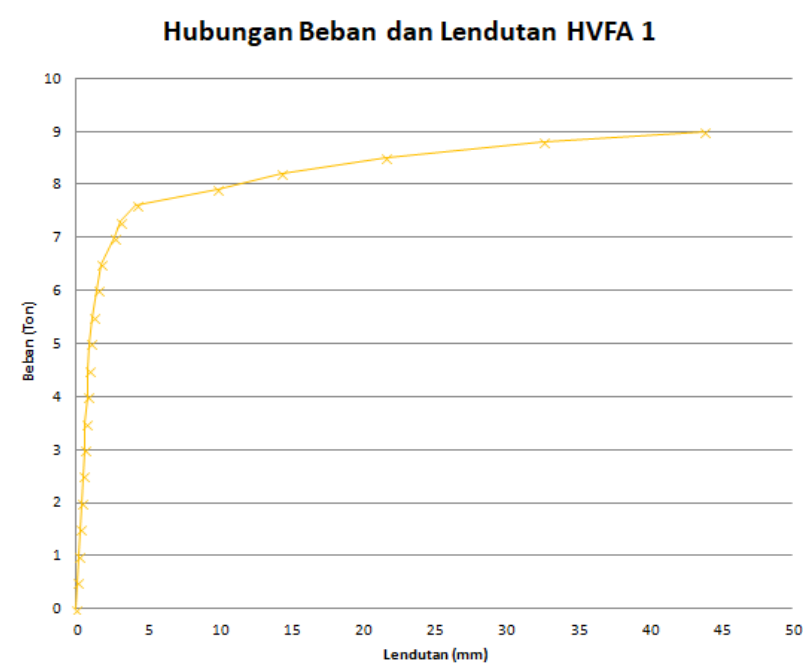

Gambar 7. Hubungan Beban dan Lendutan Balok HVFA 1

Hubungan Beban dan Lendutan HVFA 3

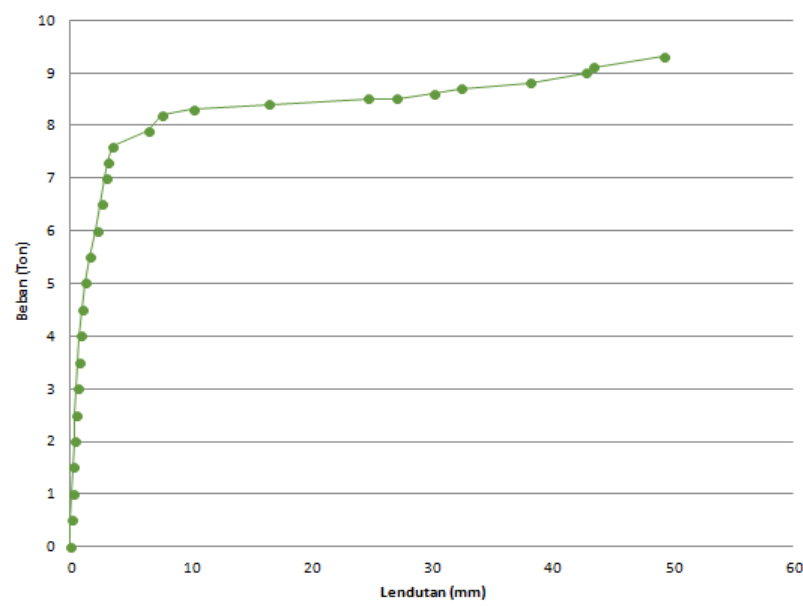

Gambar 9. Hubungan Beban dan Lendutan Balok HVFA 3

Gambar grafik diatas menunjukan lendutan yang terjadi pada balok beton bertulang untuk setiap beban yang bekerja hingga akhirnya balok mengalami keruntuhan. Pengambilan data dilakukan pada lokasi bentang tengah balok, dimana dial load diletakkan dibawah balok dengan lokasi center terhadap bentang horisontal balok.

Berdasarkan grafik hubungan beban dan lendutan pada balok beton normal dan balok beton HVFA-SCC 50\% di atas terlihat bahwa nilai lendutan akan meningkat seiring dengan penambahan beban. Pada awal pembebanan 
grafik menunjukan hubungan linier antara beban dan lendutan, artinya besarnya nilai pertambahan lendutan selalu proporsional untuk setiap penambahan beban. Pada beban tertentu grafik mengalami perubahan, pertambahan nilai lendutan tidak lagi proporsional untuk setiap penambahan beban maka penambahan sehingga grafik menjadi tidak linier lagi. Perubahan hubungan ini terjadi karena tulangan baja pada balok mulai mengalami leleh pertama, sehingga nilai lendutan akan semakin besar seiring bertambahnya beban hingga akhirnya balok mengalami keruntuhan.

Setelah tulangan mengalami leleh pertama terjadi perbedaan bentuk grafik lendutan antara beton normal dan beton HVFA-SCC 50\%. Beton HVFA-SCC 50\% yang diuji pada umur 56 hari memiliki nilai lendutan maksimum yang besar dibandingkan beton normal yang diuji pada umur 28 hari. Hal ini disebabkan oleh penambahan fly ash yang berfungsi sebagai filler mampu meningkatkan nilai daktailitas pada beton. Perilaku tersebut tentunya akan menyebabkan perubahan pada kurva tegangan-regangan pada beton. Perubahan kurva tegangan-regangan pada balok beton akan menyebabkan perubahan bentuk blok tegangan ekuivalen, sehingga perlu dilakukan analisis modifikasi perhitungan momen ultimate balok beton HVFA-SCC 50\%.

Pada pengujian ini juga dilakukan pencatatan terhadap keretakan yang terjadi pada penampang balok, sehingga dari grafik ini terdapat tiga perilaku struktur penting yang menjadi pembahasan nilai kapasitas lenturnya. Perilaku tersebut meliputi kondisi beton saat mengalami retak pertama, saat mengalami leleh pertama, serta kondisi ultimate.

\section{SIMPULAN}

Dari hasil pembahasan diatas dapat diambil beberapa simpulan sebagai berikut :

1. Balok beton bertulang HVFA-SCC memiliki lendutan yang lebih besar dari pada balok beton bertulang normal.

2. Balok beton bertulang normal dapat menerima beban yang lebih besar dari pada balok beton bertulang HVFA-SCC.

\section{UCAPAN TERIMA KASIH}

Ucapan terima kasih penulis sampaikan kepada Bapak Agus Setiya Budi, S.T., M.T. dan Bapak Prof. Stefanus Adi Kristiawan, S.T., M.Sc., Ph.D. selaku pembimbing yang dengan penuh kesabaran telah memberi koreksi dan arahan sehingga menyempurnakan penyusunan. Rasa terima kasih penulis sampaikan khusus untuk tim Beton Sabar selaku tim kerja yang pantang menyerah.

\section{REFERENSI}

Anonim. 2000. "SN1 03-2834-2000, "Tata Cara Pembuatan Rencana Campuran Beton Normal". Badan Standarisasi Nasional, Jakarta.

Anonim. 2004. "SNI 15-2049-2004 Semen Portland". Badan Standardisasi Nasional, Jakarta." Badan Standarisasi Nasional, Jakarta.

Anonim. 2005. The European Guidelines for Self-Compacting Concrete Specification, Production and Use. The European Federation of Specialist Construction Chemicals and Concrete Systems (EFNARC).

Anonim. "Standard Test Method for Passing Ability of Self-Consolidating Concrete by J-Ring", American Society for Testing of Concrete's.". ASTM C 1621M. 1991.

Anonim. "Standard Standard Specification for Concrete Aggregates". ASTM C33. 1991.

Anonim. "Standard Test Method for Compressive Strength of Concrete", American Society for Testing of Concrete's. ASTM C39/C39M. 1991.

Anonim. "Standard Test Method for Fly Ash and Row or calcined Natural Pozzolan for Use as a mineral Admixture in Portland Cement Concrete", American Society for Testing of Concrete's". ASTM C 618-93. 1991.

Arezoumandi, M., Ortega, C. A., \& Volz, J. S. 2014. Flexural Bebavior Of High-Volume Fly Ash Concrete Beams Experimental Study. Paper presentation at the TRB 94th Annual Meeting and for publication in TRB's Journal.

Avri Priatma. 2012.”Pengaruh Kadar Fly Ash sebagai Pengganti Sebagian Semen terhadap Kuat Tarik Belah dan Modulus of Rupture pada High Volume Fly Ash-Self Compacting Concrete". Universitas Sebelas Maret. 
Desi Candra Kurniawati. 2016. Perilaku Lentur Balok Beton Bertulang Jenis High Volume Fly Ash-Self Compacting Concrete (HVFA - SCC), Skripsi, Progam Studi Teknik Sipil Universitas Sebelas Maret. Surakarta.

Gere and Timoshenko. "Mekanika Bahan”. Erlangga : Jilid II Edisi 4. Jakarta.

G. Venkatesan, S. Reghu R., and M. Chandra S.,.2013. Flexural behaviour of reinforced concrete beams using high volume fly ash concrete confinement in compression zone. Journal of Civil Engineering (IEB), 41 (2) (2013) 87-97. India.

Kardiyono Tjokrodimuljo. 1996.”Teknologi Beton”.Fakultas Teknik Universitas Gadjah Mada.

M. Solikin. 2012. Pemanfaatan Abu Terbang untuk Mengurangi Limbah Terbuang PLTU dengan Teknologi High Volume Fly Ash (HVFA) Concrete, Laporan Tahun 1 Penelitian Hibah Bersaing Universitas Muhammadiyah. Surakarta.

Okamura, H. and Ouchi, M. 2013. Self-Compacting Concrete. Journal of Advanced Concrete Technology Vol. 1, No.1, 5-15, April 2013. Japan Concrete Institute

.Susuilorini, M.I. Retno dan Kusno Adi Sambowo. 2011. Teknologi Beton Lanjutan Durabilitas Beton. Surya Perdana Semesta (SPS). Semarang.

Tito Adhi Yansyah. 2017. Kapasitas Lentur Balok Beton Bertulang High Volume Fly Ash Self Compacting Concrete (HVFA-SCC), Skripsi, Progam Studi Teknik Sipil Universitas Sebelas Maret. Surakarta. 